are made to determine proper seasons of range use, the class or classes of livestock that can use the range most beneficially, and the feasibility of withdrawing from use certain areas to effect rehabilitation by both artificial and natural means.

The problem of range management involves a study of the relationship between private and public land and the devising of plans to make the use of all the lands compatible with the available resources and the economic structure. Range improvements consisting of water development, re-seeding, erosion control works, trails and other facilities, and the elimination of undesirable elements such as rodents, predators and poisonous plants are included in the programme.

Units to facilitate particular administrative objectives and to localize problems in conformity with community and region welfare assure a broad attack on social and economic, as well as physical fronts. By this means the programme is enabled to outline and develop a type of land use that, in the end, will ensure the stability of the unit involved. In turn, this unit, whether it be a grazing district, a national forest, an Indian reservation, a game range, or any suitable allotment or portion thereof, will reflect the benefits derived on the public welfare generally.

\section{LAND UTILIZATION AND Fish CONSERVATION}

\section{By Elmer Higgins, Bureau of Fisheries}

Land utilization and water utilization are closely related. Water utilization affects aquatic life through changes in habitat. No other group of vertebrates is so delicately adjusted to environment as are fishes. Sudden changes in the nature of environment afford the fishes no opportunity to escape, and death is the only alternative.

Land uses and abuses that have contributed to the diminution of our resources in fresh-water and anadromous fishes, including the effects of agriculture and lumbering, mining operations, petroleum extraction, manufacturing, and the development of urban life and recreational areas are all important. Land restoration practices that do not conserve fish-life include irrigation, power development, canalization of streams, and the draining of sub-marginal lands. Land restoration practices that aid in fish conservation or can be adapted to conservation objectives include erosion control, flood control, pollution abatement, and properly designed water impoundments.

The diversity of interests in land and water utilization demands the development of a co-ordinated conservation programme, particularly with respect to water conservation. The objectives of such a programme may be summed up as follows: The adoption of general principles of water conservation will aid in fishery conservation if the requirements of aquatic life are taken into account when water utilization projects are being planned. In general, the water should be kept on the land, rapid run-off retarded, flood waters stored, erosion prevented, pollution prohibited, canalization of streams minimized, irrigation canals screened, impoundments operated with minimum fluctuation of water-level, dams constructed with outlets at base to improve circulation in reservoirs and provided with fishways where important runs of fishes are obstructed.

\title{
SOCIAL STATISTICS OF MERSEYSIDE
}

\begin{abstract}
rTHE "New Handbook of Social Statistics relating to Merseyside" prepared by the Statistics Division, Social Science Department, the University of Liverpool (University Press of Liverpool, 1940. ls. net), gives a statistical statement of the position on Merseyside in relation to trade, employment and other social conditions immediately before the outbreak of war. The sections on elementary education and housing have been omitted and rather more material is included relating to the changing state of employment. The first section on the trend of births, deaths and population directs attention to the continuous and steep fall in the birth-rate until the last few years, the level reached in 1938 being about two thirds of that recorded in the 1911-15 quinquennium. The trends of the general death-rate and infant mortality-rate show no evidence of great scope for a further reduction of the general death-rate, and infant mortality is unlikely to decline at the rate experienced in the earlier years of the century. In each of the four boroughs there appears to have been a more or less stable position by 1938 , with even a slight tendency to a natural increase in population.

Figures given for the trade of the Port of Liverpool in comparison with that of London, Hull, Southampton and Manchester show that between 1932 and 1938 import values rose by 30 per cent in both London and Liverpool, while export values increased
\end{abstract}

by 50 per cent in London but only by 24 per cent in Liverpool. Articles wholly or mainly manufactured account for $£ 120$ millions out of $£ 139$ millions exported from Liverpool in 1938, but represent only about one eighth of the goods entering Liverpool. In regard to imports of foods, certain foods touched their lowest point in $1935-37$, afterwards rising to about two thirds of their value in 1927-29, whereas the value of every imported raw material listed was higher in $1935-37$ than in 1930-32, generally receding again slightly in 1938.

Since 1927-29, the number of insured persons on Merseyside has increased from 362,000 to 424,000 , while the number of unemployed rose from 57,000 in 1930 to the 100,000 level in 1935 , declining to 80,000 by the middle of 1939. The tables indicate a decline in shipping and shipbuilding over the last ten years and in transport and distribution since 1932, with expansion in metals and engineering and in general service. Shipping and shipbuilding, transport and distribution, now account for only 41 per cent of the total of insured workers as against one half ten years ago. General service, however, has increased from 12 per cent in 1929 to nearly 18 per cent. Taking all industries, the number of insured-workers employed in 1939 was 12 per cent above the 1929 level on Merseyside and 18 per cent above that level in the country as a whole. With regard to unemployment, 
while in comparison with 1932 all industrial groups show decreases in the percentage of insured workers unemployed, varying from 22 in transport and distribution to 67 in metals and engineering, Merseyside shortly before the War had still a percentage of unemployment of 18.8 as against $9 \cdot 6$ in Great Britain and Northern Ireland as a whole.

Analysis of the unemployment situation indicates that out of nearly 80,000 unemployed, 35,000 may be regarded as normal, 8,400 must be attributed to the abnormal times from which all parts of the country have suffered, and 36,000 to the exceptional character of Merseyside. One half of the normal unemployment on Merseyside is accounted for by the shipping, shipbuilding and related industries, where a high proportion of the total is made up of dockers and other casual workers. The general rise in unemployment among women since February 1939, while unemployment generally had decreased by nearly 24,000 (February 1940), is attributed to the much greater transfer of men to the heavy industries and to other war-time production and to the services. The number of unemployed clerks, typists and bookkeepers increased from 592 in 1939 to 2,731 in 1940, due to the closing down or contraction of businesses engaged in the manufacture or distribution of commodities not essential for life and a moderate degree of comfort and for the prosecution of the War. Unemployed boys between 14 and 17 years of age decreased by 22 per cent and girls by 5 per cent when the average of 1939 is compared with 1938 , while for boys the February 1940 figure was 18 per cent better than the February 1939 figure, the March figure being 39 per cent better than last year's. For girls the February unemployed total was 57 per cent greater than the 1939 figure, but for March 1940 the figure was only 34 per cent greater than that of March 1939.

For the combined unemployment benefit and unemployment allowances, the expenditure during four weeks in 1939 was $£ 387,544$ as against $£ 280,530$ in the corresponding weeks in 1940. The total number of persons in receipt of relief in the combined Merseyside boroughs fell from 58,000 in March 1939 to 48,000 in March 1940, with a decline in expenditure from $£ 75,689$ to $£ 71,441$ for the corresponding four weeks. The local rates have been increased only slightly for 1940-41, increases due to civil defence measures being offset to some extent by savings under 'black-out' regulations.

\section{FISHERIES RESEARCH IN HONG KONG*}

$\mathrm{I}^{\mathrm{T}}$ does not often happen that the official publication of a research station makes its appearance before the erection of the station itself has even begun; and certainly this enterprising inauguration of the Journal of the Hong Kong Fisheries Research Station will be most gratifying to those who have persistently advocated and worked for the establishment of fishery science throughout the British Empire. Tribute will be paid to Dr. Herklots, the editor of the Journal and honorary director of the Station, whose organizing ability and unbounded enthusiasm inspire confidence in the future of the work at Hong Kong, despite the tremendous difficulties occasioned by wars to which both the British and Chinese peoples are unhappily committed.

Since the primary purpose of the Station is to study the fishes of the South China seas and the fishing techniques employed by the local fishermen with a view to the future benefit of the fishing industry, it is appropriate that the early numbers of the Journal should be devoted to a general survey of the Hong Kong fisheries. Dr. Lin makes a good beginning with his detailed and well-illustrated account of the boats, gear and fishing methods. It is the story of a remarkable people who make their permanent homes and live their lives in the fishing junks with their families. Men and women, and girls and boys above the age of fifteen, form the fishing personnel; family life proceeds in specified quarters; and a shrine for worship is always to be found in the heart of the ship.

The junk trawlers, varying from 50 to 90 feet in length, are perhaps the biggest and most important fishing vessels employed in China. It is claimed that there are about a thousand registered in Hong Kong, all operated and many owned by the floating popula-

*Journal of the Hong Kong Fisheries Research Station. Edited by G. A. C. Herklots, Vol. 1, No. I, Feb. 1940. Pp. 1-101 with frontispiece, 6 plates and 48 flgs. in text. (Hong Kong: The South China Morning Post, Ltd.). 3 dollars. tion of Kwangtung and Hong Kong. Save for the smaller forms, all the trawling junks are threemasted wooden vessels with the bow comparatively low and the stern very high. No wheel house is provided and the detachable, heavy rudder is manipulated by means of the tiller on the high stern. Sleeping places for the crew are located below deck in front of, or behind, the main mast; the shrine is always situated in a hold immediately in front of the aft hold. On the stern, several rooms are constructed above the poop to accommodate the owner's family and the galley. Drinking water is kept in holds either on both sides of the main mast or behind it. The fishing gear, ice, salt and the catches are stored in special holds between the main mast and the stern. A long roller for hauling in the trawl is fitted with 8-10 handles and operated by $8-10$ members of the crew, and is situated either on the starboard side behind the main mast or transversely in front of it. The anchors are manipulated by capstan. The sails are constructed of mats in preference to canvas; the latter is the better material for sail-making but is too light to be easily lowered or swung from one side to the other with the speed required during fishing operations.

Giving equally interesting details, Dr. Lin goes on to describe beam-trawlers, purse-seine and drag-seine junks, and long-liners. Next he deals with the personnel, varying from 6 to 25 persons per junk, most of whom are hired on a time-wage basis with (sometimes) a bonus on the value of the catch. As most of the fishermen know the whole process of fishing and the different tasks on board are sufficiently straightforward, there is no special allotment of duties, and all interchange freely. Eight types of fishing gear are used, all of which should be of particular interest to students of British fisheries, since there is much to be learned from them which might well prove serviceable in home waters. E. F. 